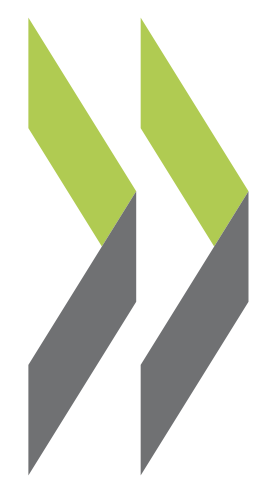

OECD Economics Department Working Papers No. 816

\title{
A Simple Model \\ of the Relationship Between Productivity, Saving and the Current Account
}

Jean-Marc Fournier, Isabell Koske 
Organisation de Coopération et de Développement Économiques

Organisation for Economic Co-operation and Development

23-Nov-2010

ECONOMICS DEPARTMENT

English - Or. English

A SIMPLE MODEL OF THE RELATIONSHIP BETWEEN PRODUCTIVITY, SAVING AND THE CURRENT ACCOUNT

ECONOMICS DEPARTMENT WORKING PAPERS No. 816

by Jean-Marc Fournier, Isabell Koske

All OECD Economics Department Working Papers are available on the OECD Intranet website at www.oecd.org/eco/workingpapers

JT03293068

Document complet disponible sur OLIS dans son format d'origine

Complete document available on OLIS in its original format 


\section{ABSTRACT/RÉSUMÉ}

\section{A simple model of the relationship between productivity, saving and the current account}

This paper uses a simple dynamic stochastic general equilibrium model to explore the qualitative impact of productivity shocks on current account positions via their impact on the saving behaviour of households. The analysis shows that the direction of the impact is ambiguous from a theoretical point of view. This impact depends in particular on consumer's willingness to shift consumption over time relative to their willingness to shift consumption between different types of goods, on whether they believe the shock to be temporary or permanent, and on the sector in which the shock occurs.

JEL Classification: E21; F32; O40

Keywords: Saving; current account adjustment; productivity

$* * * * *$

\section{Un modèle simple reliant la productivité, l'épargne et la balance courante}

Cet article explore l'effet qualitatif de chocs de productivité sur la balance courante, via leur impact sur le comportement d'épargne des ménages, avec un modèle d'équilibre général stochastique simple. Cette analyse montre que le sens de l'effet est théoriquement ambigu. Cet effet dépend de la propension des consommateurs à modifier le niveau de leur consommation au cours du temps comparée à leur propension à modifier leur panier de biens, de la croyance par les agents que le choc est permanent ou temporaire, ou encore du secteur dans lequel le choc se produit.

Classification JEL ; E21 ; F32 ; O40

Mots-clefs : Épargne ; ajustement de la balance courante ; productivité

Copyright $(9)$ OECD, 2010. All rights reserved. Application for permission to reproduce or translate all, or part of, this material should be made to: Head of Publications Service, OECD, 2 rue André-Pascal, 75775 PARIS CEDEX 16, France. 


\section{TABLE OF CONTENTS}

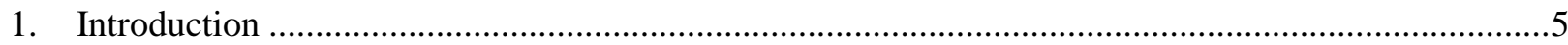

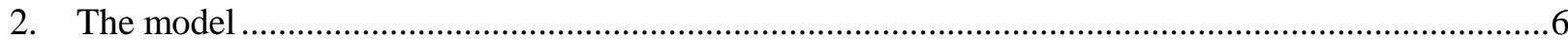

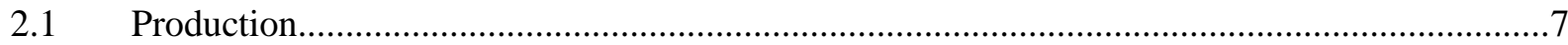

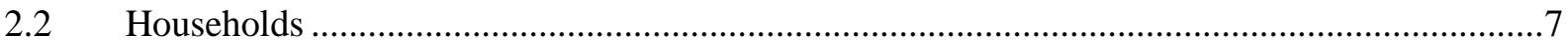

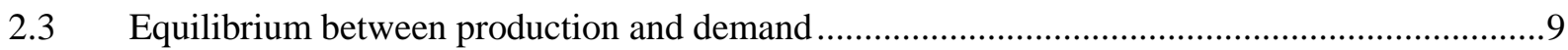

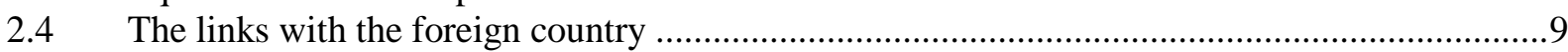

3. Simulating the impact of productivity shocks on saving and the current account..........................11

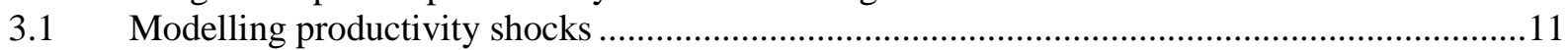

Calibration of the model parameters ............................................................................ 12

3.3 A uniform productivity shock to the whole economy ..................................................13

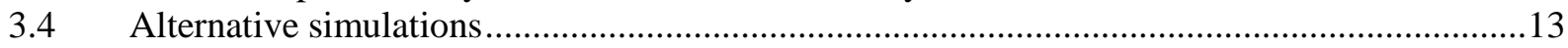

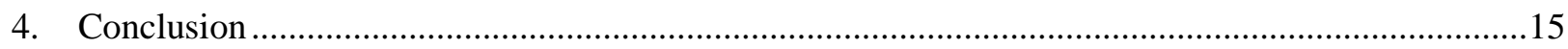

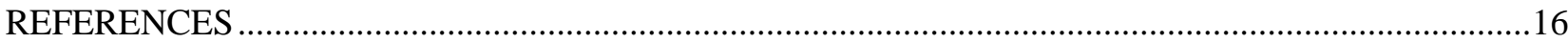

\section{Tables}

1. The response of the current account to changes in productivity ................................................. 11

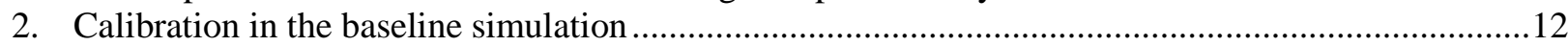

\section{Figures}

1. Permanent economy-wide productivity shock - alternative values for the speed of adjustment of productivity to its new steady state...

2. Temporary economy-wide productivity shock - alternative values for the inter-temporal elasticity of substitution ....

3. Permanent economy-wide productivity shock - alternative values for the inter-temporal elasticity of substitution .

4. Permanent productivity shock in the tradable goods sector .......................................................20

5. Permanent productivity shock in the non-tradable goods sector - alternative values for the inter-temporal elasticity of substitution 
ECO/WKP(2010)72 
ECO/WKP(2010)72

\title{
A SIMPLE MODEL OF THE RELATIONSHIP BETWEEN PRODUCTIVITY, SAVING AND THE CURRENT ACCOUNT
}

\author{
by \\ Jean-Marc Fournier, Isabell Koske ${ }^{1}$
}

\section{Introduction}

1. Structural reforms affect productivity growth, and through this channel may have side effects on saving, investment and current accounts. For this reason, reforms in some countries have been advocated in the G20 context as one of the policy tools to address global imbalances (e.g. de Mello and Padoan, 2010; IMF, 2010). The link between productivity and current account positions can be explored through empirical analysis (e.g. Kerdrain et al., 2010) or, alternatively, a model-based approach. This paper belongs to the latter category, illustrating the impact of productivity shocks on current account positions with the help of a dynamic stochastic general equilibrium (DSGE) model. A model-based approach allows to distinguish between different types of shocks (e.g. temporary versus permanent shocks) for which empirical identification is inherently difficult, and provides a better understanding of the transmission mechanisms of shocks. By definition, DSGE analysis also has the advantage of generating general equilibrium results.

2. The model used in this paper is a particular case of that developed by Ferrero et al. (2010). More precisely, this version of the model features flexible prices, and thereby abstracts from all nominal issues including the responses to shocks of inflation and monetary policy. ${ }^{2}$ In addition, the model abstracts from investment, thereby focussing on the links between productivity and saving behaviour. While the model allows investigating the indirect effects of structural policies on saving and current accounts via changes in productivity growth, it does not allow exploring other potential channels, such as the impact of labour market reforms on the precautionary saving behaviour of households. The paper is organized as follows: Section 2 first presents the main features of the model, and section 3 then assesses the impact of different types of productivity shocks on key macroeconomic variables. Finally, the last section concludes.

3. The analysis shows that the direction of the impact of productivity shocks on current accounts is ambiguous from a theoretical point of view, depending in particular on consumer's willingness to shift consumption over time relative to their willingness to shift consumption between different types of goods, on whether they believe the shock to be temporary or permanent, and on the sector in which the shock occurs. In particular, the following main conclusions emerge from the analysis:

1. The authors are members of the Structural Surveillance Division of the OECD Economics Department. They would like to thank Jørgen Elmeskov, Jean-Luc Schneider, Romain Duval, Clovis Kerdrain, Andrea Ferrero, Pierre-Alain Pionnier and Aurélien Poissonnier for their valuable inputs, suggestions and comments, as well as Celia Rutkoski and Olivier Besson for excellent editing support. Any errors are the responsibilities of the authors alone. The views expressed in this paper are those of the authors, and do not necessarily reflect those of the OECD or its member countries.

2. Incorporating sticky prices and monetary policy would change the short-term response to shocks but would not alter their longer-term consequences. 
- The immediate impact of a gradual and ultimately permanent rise - and correctly interpreted as such by households - in overall productivity hinges crucially on consumers' willingness to shift consumption over time (the inter-temporal elasticity of substitution) relative to their willingness to shift consumption between different types of goods (the intra-temporal elasticity of substitution). If households have a high propensity to smooth consumption over time, a reform that boosts aggregate productivity will be associated with a weakening of the current account position in the short run as consumers try to benefit from the future rise in income to consume more already today. This temporary deterioration in the current account is then gradually reversed as productivity rises towards its new level. By contrast, the current account may strengthen in the immediate aftermath of a reform if consumers have a low propensity for intertemporal consumption smoothing, because households then postpone their consumption increase to benefit from lower prices in the future as productivity rises (all else equal, the expected fall in future prices leads to a higher real rate of interest; see also Dornbusch, 1983).

- Reforms that boost productivity solely in the tradable goods sector unambiguously lead to a weakening of the current account in the short run, which is then gradually reversed once the productivity increase sets in. The short-run current account reaction is driven by two factors: first, consumers try to benefit from the future rise in income by consuming more already today and, second, they frontload consumption since the relative price of non-tradable goods is expected to rise in the future. Since both effects work in the same direction, the magnitude of the current account reaction is larger than in the case of an economy-wide shock - under which the second effect partially offsets the first, or even outweighs it if consumers have a low propensity to smooth consumption over time. ${ }^{3}$

- If a productivity shock is only temporary or if households incorrectly believe that a permanent productivity boost is only temporary and they have a strong preference for keeping their level of consumption stable over time, the current account temporarily strengthens as households save part of the higher income for the future.

\section{The model}

4. There are two symmetric countries (home and foreign) with two sectors, the tradable sector, where firms produce tradable goods that can be exported or consumed within the country, and a nontradable sector, where firms produce non-tradable goods that can only be consumed domestically. For simplicity, the model abstracts from capital accumulation and assumes that labour is the only production factor. ${ }^{4}$ The underlying growth rates of the two economies are set to zero. In both countries, consumers have an infinite living horizon and perfect foresight. Therefore, they anticipate the consequences of the shocks and adjust their consumption and labour supply accordingly. Consumption consists of a basket of non-tradable goods, home-made tradable goods and foreign-made tradable goods.

3. For structural reforms that boost productivity only in the non-tradable goods sector, the direction of the short-run current account reaction is again ambiguous and depends on consumers' willingness to shift consumption over time relative to their willingness to shift consumption between different types of goods, similarly to the consequences of an economy-wide shock.

4. While this limits the scope of the analysis, it keeps the model simple and thereby enables a more intuitive presentation of the links between productivity and saving. Moreover, adding capital accumulation would not alter the conclusion of the paper that the current account effects of productivity changes are ambiguous. Rather, it would add further sources of ambiguity. For instance, as shown by Obstfeld and Rogoff (1996), the sign of the current account effect would then also depend on the persistency of the shock. 


\subsection{Production}

5. Let $H$ denote the tradable good and $N$ the non-tradable good produced at home. ${ }^{5}$ In each of the two sectors $k \in\{H, N\}$ of the home country, a representative firm uses labour to produce a final good $Y_{k t}{ }^{6}$

$$
Y_{k t}=e^{a_{t}+a_{k t}} L_{k t}
$$

where $t$ denotes time, $e^{a_{t}}$ is the economy-wide component of productivity that is common to both sectors and $e^{a_{k t}}$ is the sector $k$-specific component. The model assumes that workers cannot move between the tradable and non-tradable sectors. ${ }^{7}$

\subsection{Households}

6. Rational households are assumed to maximize their utility which is growing not only in their present and future consumption, but also in their present and future leisure. Households thus maximize the following inter-temporal utility function:

$$
U_{t} \equiv E_{t} \sum_{s=t}^{+\infty} \beta^{s-t}\left[\frac{C_{t}^{1-1 / \theta}}{1-1 / \theta}-\gamma \frac{L_{H t}^{1+\varphi}}{1+\varphi}-(1-\gamma) \frac{L_{N t}^{1+\varphi}}{1+\varphi}\right]
$$

where $C_{t}$ is aggregate consumption, $\beta$ is the discount rate, $L_{k t}$ is the amount of labour in sector $k, \gamma$ is the share of the tradable goods sector in the economy, $1 / \varphi$ is the Frish elasticity of labour and $\theta>0$ is the intertemporal elasticity of substitution. The smaller $\theta$, the more consumers are concerned about smoothing their consumption over time.

7. Defining the tradable good as the numeraire, households' budget constraint is given by:

$$
P_{t} C_{t}+\Delta B_{t}=i_{t} B_{t-1}+\gamma W_{H t} L_{H t}+(1-\gamma) W_{N t} L_{N t}
$$

where $P_{t}$ is the price of the aggregate good, $i_{t}$ the interest rate expressed in terms of traded goods, $B_{t}$ the net asset holdings of households, and $W_{k t}$ the wage per unit of time in sector $k$. The net asset holdings of households consist of an internationally traded bond and, given the absence of a physical capital stock, are equal to the net foreign asset position. The right hand-side of the budget constraint writes household income $I_{t}$ in period $t$ as the sum of wage income and net interest payments, i.e. $I_{t}=\gamma W_{H t} L_{H t}+(1-\gamma) W_{N t} L_{N t}+i_{t} B_{t-1}$. The household allocates this income to consumption $P_{t} C_{t}$ and to saving $\Delta B_{t}$, as shown on the left hand-side of the equation.

8. Maximizing the utility function (2) subject to the budget constraint (3) yields the Euler equation with perfect foresight:

5. This symmetric model also includes foreign counterparts of the equations that are not presented here.

6. Alternatively, a continuum of small firms could be considered, without any implications for the main results.

7. This simplification implies that the conclusions that are drawn from the model should be considered as applying mostly to the short to medium run. 


$$
E_{t}\left(\beta\left(1+i_{t}\right) \frac{P_{t}}{P_{t+1}}\left(\frac{C_{t+1}}{C_{t}}\right)^{-1 / \theta}\right)=1
$$

9. Total consumption consists of both tradable goods $C_{T t}$ and non-tradable goods $C_{N t}$, and the elasticity of substitution between them is set equal to one:

$$
C_{t} \equiv \frac{C_{T t}^{\gamma} C_{N t}^{1-\gamma}}{\gamma^{\gamma}(1-\gamma)^{(1-\gamma)}}
$$

With households minimising expenditure costs, the index for the nominal price of the composite consumption good $P_{t}$ is given by:

$$
P_{t}=P_{N t}^{1-\gamma} P_{T t}^{\gamma}=P_{N t}^{1-\gamma}
$$

In nominal terms, utility maximization implies that the share of consumption allocated to tradable goods is constant:

$$
C_{T t}=\gamma P_{t} C_{t} \text { and } P_{N t} C_{N t}=(1-\gamma) P_{t} C_{t}
$$

and total consumption in nominal terms is the simple sum of tradable and non-tradable consumption $C_{T t}+P_{N t} C_{N t}=P_{t} C_{t}$.

10. Consumption of tradable goods consists of consumption of home-made tradables $C_{H t}$ and foreignmade tradables $C_{F t}$ :

$$
C_{T t} \equiv\left[\alpha^{1 / \eta} C_{H t}^{\frac{\eta-1}{\eta}}+(1-\alpha)^{1 / \eta} C_{F t}^{\frac{\eta-1}{\eta}}\right]^{\frac{\eta}{\eta-1}}
$$

where $\eta$ is the elasticity of substitution between home-made and foreign-made tradable goods and $\alpha$ is the share of home-made tradables in the total consumption of tradables. Minimization of expenditure costs implies:

$$
1=\left[\alpha P_{H t}^{1-\eta}+(1-\alpha) P_{F t}^{1-\eta}\right]^{\frac{1}{1-\eta}}
$$

Utility maximization leads to:

$$
C_{H t}=\alpha P_{H t}^{-\eta} C_{T t}, \quad C_{F t}=(1-\alpha) P_{F t}^{-\eta} C_{T t} \text { and } P_{H t}^{\eta} C_{H t}+P_{F t}^{\eta} C_{F t}=\alpha C_{T t}+(1-\alpha) C_{T t}=C_{T t}
$$

11. Assuming that the firm acts competitively in the labour market within each sector, the real wage in sector $k$ is equal to the marginal productivity of labour:

$$
\frac{W_{k t}}{P_{k t}}=e^{a_{t}+a_{k t}}
$$


Maximization of the utility function (2) with respect to the amount of labour subject to the budget constraint (3) yields the following labour supply equation:

$$
L_{k t}^{\varphi}=\frac{W_{k t}}{P_{t} C_{t}}
$$

The propensity to work increases with the real wage but declines with the level of consumption, reflecting decreasing marginal utility of consumption. The higher $\varphi$, the more rigid the supply of labour.

12. Rewriting the Euler equation in terms of the consumption rate shows that this rate depends on the real interest rate $i_{t}$ expressed in terms of traded goods, the change in the price of non-tradable goods relative to the price of tradable goods $P_{N t+1} / P_{N t}$, and the change in real income $\left(I_{t+1} / P_{t+1}\right) /\left(I_{t} / P_{t}\right)$ :

$$
\left(\frac{P_{t+1} C_{t+1} / I_{t+1}}{P_{t} C_{t} / I_{t}}\right)^{1 / \theta}=\beta\left(1+i_{t}\right)\left(\frac{P_{N t+1}}{P_{N t}}\right)^{-(1-\gamma)}\left(\frac{I_{t+1} / P_{t+1}}{I_{t} / P_{t}}\right)^{-1 / \theta}
$$

Equation (13) provides useful insights into the behavior of consumers. A rise in the real interest rate reduces current consumption in favour of the future since future consumption becomes relatively cheaper. By the same token, a rise in the relative price of non-tradable goods raises consumption today. Moreover, a rise in real income pushes up current consumption relative to future consumption with the size of this effect rising in the value of the inter-temporal elasticity of substitution.

\subsection{Equilibrium between production and demand}

13. In equilibrium, all product markets clear. Aggregate production of non-tradables is equal to the aggregate consumption of non-tradables:

$$
Y_{N t}=C_{N t}=\frac{(1-\gamma) C_{t}}{P_{N t}}
$$

and the production of tradables at home is equal to the sum of consumption of home-made tradables at home and abroad (the latter being equal to exports):

$$
\begin{aligned}
Y_{T t} & =C_{H t}+C_{F t}^{*} \\
& =\alpha\left(\frac{P_{H t}}{P_{T t}}\right)^{-\eta} C_{T t}+(1-\alpha)\left(\frac{P_{F t}^{*}}{P_{T t}^{*}}\right)^{-\eta} C_{T t}^{*}
\end{aligned}
$$

\subsection{The links with the foreign country}

14. The law of one price holds for tradables:

$$
P_{H t}=E_{t} P_{H t}^{*} ; P_{F t}=E_{t} P_{F t}^{*}
$$

where $E_{t}$ is the nominal exchange rate and the asterisk denotes the foreign country. With this definition, a decline in the value of $E_{t}$ means that the home currency appreciates. The terms of trade are defined as the ratio of the home-currency price of foreign-made tradable goods to the home-currency price of home-made tradable goods where again a decline in the value of $T_{t}$ means an improvement in the terms of trade: 


$$
T_{t} \equiv \frac{P_{F t}}{P_{H t}}
$$

Equation (16) determines the real exchange rate $E_{t} P_{t}^{*} / P_{t}$, where $P_{t}^{*}$ denotes the price of aggregate consumption abroad, as a function of the relative prices of non-tradables at home and abroad and the terms of trade: ${ }^{8}$

$$
\frac{E_{t} P_{t}^{*}}{P_{t}}=\frac{E_{t}\left[\alpha P_{H t}^{* 1-\eta}+(1-\alpha) P_{F t}^{* 1-\eta}\right]^{\frac{1}{1-\eta}}\left(P_{N t}^{*}\right)^{1-\gamma}}{\left[\alpha P_{H t}^{1-\eta}+(1-\alpha) P_{F t}^{1-\eta}\right]^{\frac{1}{1-\eta}}\left(P_{N t}\right)^{1-\gamma}}=\left[\frac{\alpha T_{t}^{1-\eta}+(1-\alpha)}{\alpha+(1-\alpha) T_{t}^{1-\eta}}\right]^{\frac{1}{1-\eta}}\left(\frac{P_{N t}^{*} / P_{T t}^{*}}{P_{N t} / P_{T t}}\right)^{1-\gamma}
$$

The real exchange rate thus appreciates with a rise in the relative price of non-tradable goods in the home country, a decline in the relative price of non-tradable goods in the foreign country and, given home bias, an improvement in the terms of trade.

15. By definition, with no investment in the model, the current account is equal to saving $\Delta B_{t}$ :

$$
C A_{t}=B_{t}-B_{t-1}
$$

With zero economic growth, the net foreign asset position $B_{t}$ must be constant in the steady state, implying that the current account must be equal to zero.

16. The model is closed by requiring international financial markets to clear, so that the sum of all financial asset positions is zero:

$$
B_{t}^{*}+B_{t}=0
$$

where $B_{t}^{*}$ is the bond held abroad denominated in home currency. This relationship means that the demand for assets in a country must equal the supply of assets abroad. Since the demand for assets depends on the interest rate, this relationship implicitly defines the world interest rate level.

17. The change in net foreign assets can also be expressed as the sum of net exports $N X_{t}$ and financial payments received $i_{t} B_{t-1}$ :

$$
B_{t}=\left(1+i_{t}\right) B_{t-1}+N X_{t}
$$

where net exports are equal to the nominal value of tradables produced at home less the nominal value of total home consumption of tradables (including the imported good):

$$
N X_{t}=P_{H t} Y_{H t}-P_{T t} C_{T t}
$$

8. There is no unique solution for the nominal exchange rate and the foreign price since the model is written in real terms. 


\section{Simulating the impact of productivity shocks on saving and the current account}

\subsection{Modelling productivity shocks}

18. Two types of shocks are considered, involving either permanent or temporary shifts in the level of productivity. For this purpose, common productivity and sector-specific productivity are assumed to follow the following processes: ${ }^{9}$

$$
a_{t}=\left(1-\rho^{a}\right) \bar{a}+\rho^{a} a_{t-1}+\varepsilon_{t}^{a} \quad a_{k t}=\left(1-\rho^{a_{k}}\right) \bar{a}_{k}+\rho^{a_{k}} a_{k t-1}+\varepsilon_{t}^{a_{k}}
$$

where $\bar{a}$ is the permanent level of common productivity and $\bar{a}_{k}$ is the permanent level of sector-specific productivity, $0<\rho^{a}<1$ is a persistence parameter, and $\varepsilon_{t}^{a}$ and $\varepsilon_{t}^{a_{k}}$ are temporary economy-wide and sector specific shocks, respectively. Permanent shifts in productivity levels can be modelled as permanent changes in $\bar{a}$ and $\bar{a}_{k}$, respectively. The smaller $\rho^{a}$, the faster productivity reaches its new level, and for $\rho^{a}=0$ the diffusion of the permanent shock is instantaneous. Changes in $\varepsilon_{t}^{a}$ and $\varepsilon_{t}^{a_{k}}$, by contrast, affect productivity only temporarily. The higher $\rho^{a}$, the more persistent such temporary shocks are.

19. The following two sections discuss the macroeconomic consequences of different types of productivity shocks, and Table 1 provides an overview of the current account effects depending on the value of key model parameters. In all simulations it is assumed that, before the shock occurs, the economy is in a steady state in which the current account position is equal to zero. Productivity levels are set such that all prices are equal to unity. This initial steady state is assumed to be symmetric: the net foreign asset position is zero and accordingly, the trade balance is equal to zero as well.

Table 1. The response of the current account to changes in productivity

\begin{tabular}{lccc|cc}
\hline \multicolumn{1}{c}{ Sector } & $\begin{array}{c}\text { Inter-temporal } \\
\text { elasticity of } \\
\text { substitution } \theta\end{array}$ & $\begin{array}{c}\text { Persistence } \\
\rho\end{array}$ & Nature of shock & $\begin{array}{c}\text { Short run } \\
\text { (initial period) }\end{array}$ & $\begin{array}{c}\text { Long run } \\
\text { (new steady } \\
\text { state) }\end{array}$ \\
\hline Tradables \& non-tradables & Low & High & Permanent & - & 0 \\
Tradables \& non-tradables & High & None & Permanent & 0 & 0 \\
Tradables \& non-tradables & High & High & Permanent & + & 0 \\
Tradables \& non-tradables & High & High & Temporary & - & 0 \\
Tradables \& non-tradables & Low & High & Temporary & + & 0 \\
Tradables & High & High & Permanent & - & 0 \\
Tradables & Low & High & Permanent & - & 0 \\
Non-tradables & High & High & Permanent & + & 0 \\
Non-tradables & Low & High & Permanent & - & 0 \\
\hline
\end{tabular}

9. A second-order Taylor approximation of the expectation functions around the steady state is used to compute the impact of temporary and permanent shocks (Schmitt-Grohe and Uribe, 2002). The simulated shocks are small (a $0.1 \%$ increase in productivity), so that this approximation remains close to the exact formula. Simulating temporary shocks instead with a linearization around the steady state using the Anderson-Moore Algorithm and permanent shocks with a relaxation method (Laffargue, 1990) produces results that are very similar to those of the second-order Taylor approximation used here. Final steady-state bond positions are consistent with debt-accumulation dynamics, as in Mendoza and Tesar (1998). 


\subsection{Calibration of the model parameters}

20. The types of household preferences for consumption smoothing are the elasticity of substitution between tradable and non-tradable goods (equal to one), the elasticity of substitution between home-made and foreign-made tradable goods $\eta$, and the inter-temporal elasticity of substitution $\theta$. In the simulations, the elasticity of substitution between tradable and non-tradable goods is set equal to 1 and the elasticity of substitution between foreign and home-made tradable goods is set equal to 2 (following Ferrero et al., 2010), whereas the value of $\theta$ is varied to explore the implications of differences in the relative importance of intra- versus inter-temporal consumption smoothing for the current account reaction to productivity changes. ${ }^{10}$ Specifically, the simulation exercise varies the value of $\theta$ between 0.1 and 10 , with a baseline value equal to $1 .^{11}$

Table 2. Calibration in the baseline simulation

\begin{tabular}{l|cc}
\hline Parameter & Symbol & Value in baseline \\
\hline Inter-temporal elasticity of substitution & $\theta$ & 1 \\
Elasticity of substitution between tradable and non-tradable goods & - & 1 \\
Elasticity of substitution between home-made and foreign-made tradable goods & $\eta$ & 2 \\
Discount factor & $\beta$ & 2 \\
Inverse of the Frish elasticity of labour & $\varphi$ & 0.99 \\
Share of tradables in total consumption & $\gamma$ & 0.6 \\
Share of home-made tradables in consumption of tradables & $\alpha$ & 0.9 \\
Persistence of productivity & $\rho^{a}$ & 25 \\
\hline
\end{tabular}

21. The share of tradable goods in the economy $\gamma$ is assumed to be equal to $25 \%$, consistent with their share in large economies such as the United States, and the share of home-made tradables in the total consumption of tradables $\alpha$ is set equal to 0.6 , reflecting a small home bias in consumption. ${ }^{12}$ Following Ferrero et al. (2010), the inverse of the Frish elasticity of labour $\varphi$ is set equal to 2, consistent with evidence from micro-data. The persistence parameters $\rho^{a}$ and $\rho^{a_{k}}$ are set equal to 0.9 in all simulations but one that, for illustrative purposes, explores the implications of zero persistence. An overview of the calibrated values of all model parameters in the baseline simulation is provided in Table 2.

10. Varying instead the values of the intra-temporal elasticities of substitution yields qualitatively similar conclusions (results not shown).

11. The empirical literature has not yet reached a consensus regarding the size of $\theta$. For example, using macroeconomic data, Hall (1988) and Yogo (2004) conclude that the inter-temporal elasticity of substitution is not significantly different from zero, whereas Guvenen (2006) and Gruber (2006) obtain values of respectively 1 using macroeconomic data and 2 using household-level data. Moreover, Guvenen (2006) argues that the inter-temporal elasticity of substitution grows in the level of wealth. He also points out that in the presence of borrowing constraints that are binding for poor households, these households' consumption will closely track their income and will not respond to the interest rate unlike the consumption of wealthy (and unconstrained) households. $\theta$ may thus be interpreted as a function of both the inter-temporal elasticity of substitution and the strength of credit constraints associated with financial market regulation, so that financial market reform may imply a rise in $\theta$.

12. For $\alpha=0.5$ consumers are indifferent between home-made tradables and foreign-made tradables. 
22. This section discusses the macroeconomic consequences of a uniform permanent shift in the level of productivity in both the tradable and the non-tradable goods sectors of the home country (i.e. a shift in $\bar{a})$. Such a shock may, for example, result from the removal of competition-unfriendly product market regulations in both manufacturing and services or from improvements in the depth and sophistication of financial markets. Since the productivity impact from such structural reforms typically takes time to materialise, a progressive rise in productivity towards its new equilibrium is assumed ( $\rho^{a}=0.9$, close to unity). In this baseline simulation (Figure 1, solid line) the inter-temporal elasticity of substitution $\theta$ is set equal to unity. ${ }^{13}$

23. Households know that productivity - and hence income - will gradually rise over time and increase their desired level of consumption (of all three goods) immediately to frontload some of the benefits from higher future income. Since output rises only gradually, households initially wish to consume more goods than can be produced. To clear the market for non-tradable goods, the relative price of nontradables needs to increase. ${ }^{14}$ This change in relative prices induces consumers to shift their consumption towards tradable goods. Consumption of tradables thus increases in response to both consumption smoothing and the higher current relative price of non-tradables. The rise in tradable consumption is reflected in an increase in imports of foreign-made tradables. At the same time, the home bias causes an increase in the current price of home-made tradables relative to foreign-made tradables, meaning that exports decline. ${ }^{15}$ As total consumption in the home country exceeds income, households borrow from the rest of the world and the current account turns negative, so that the net foreign asset position begins to weaken. The negative current account balance is reflected in higher imports of foreign-made tradables and lower exports of home-made tradables.

24. As time passes, the output of both non-tradable goods and home-made tradable goods increases, reversing the initial price reactions. This induces consumers to shift consumption away from tradable towards non-tradable goods and away from foreign-made tradables towards home-made tradables. The aggregate saving rate increases, net exports rise and eventually turn positive to offset the interest payment on the accumulated net foreign debt and thereby close the current account in the steady state.

\subsection{Alternative simulations}

25. A number of alternative simulations are carried out in order to illustrate how changes in the type of the shock and the parameters of the model affect the response of the current account position. For each simulation, the values of all parameters that are not explicitly mentioned below are set equal to their baseline values. For brevity, the discussion focuses only on those results that differ from those obtained under the baseline simulation presented in the previous section.

26. While structural reforms are more likely to have a permanent rather than a temporary impact on the level of productivity, their effect on the current account also depends on whether consumers believe the

13. In this particular case $C_{t}^{1-1 / \theta} /(1-1 / \theta)$ is replaced by its limit, $\log C_{t}$.

14. Since workers cannot move between the tradable and non-tradable sectors, labour in the non-tradable sector remains unchanged and the production of non-tradable goods follows exactly the same path as productivity. While this assumption is somewhat restrictive from a longer-term perspective, it does not seem unreasonable in the short run given differing skill requirements and other existing obstacles to labour mobility.

15. This effect is re-enforced by a temporary fall in the production of home-made tradables as consumers reduce their labour supply due to the increase in consumption that reduces the marginal utility of consumption (see equation (12)). 
shock to be permanent or temporary. To explore the reactions of agents under such a belief, the model is used to simulate a temporary shock (Figure 2). If consumers believe the increase in productivity to be temporary and have a high preference to smooth consumption over time, they save part of the higher income to finance higher consumption in the future, as productivity is expected here to fall back to its original level. The short-run reaction of all variables is thus opposite to the baseline case, in which consumers expect productivity to be permanently higher. This shows the key role of expectations for the current account response to productivity shocks.

27. The size and possibly even the sign of the initial current account reaction depend on the magnitude of the inter-temporal elasticity of substitution $\theta$ (relative to the intra-temporal elasticities of substitution which are held constant). For $\theta=0.1$, the current account turns into a bigger deficit than in the baseline simulation following a rise in aggregate productivity (solid line in Figure 3) since the higher propensity to smooth consumption over time leads to a stronger increase in the desired level of consumption in the immediate aftermath of the shock, in line with equation (13) ${ }^{16}$ By contrast, for $\theta=10$ (meaning that households are relatively less concerned about inter-temporal consumption smoothing than they are about consuming a stable bundle of goods), the current account turns into surplus in the aftermath of the shock (dashed line in Figure 3). The reason is that the consumption smoothing effect is more than offset by a decline in the desired level of consumption that stems from a rise in the real rate of interest that consumers are facing, given by $\left(1+i_{t}\right)\left(P_{N t+1} / P_{N t}\right)^{-(1-\gamma)}$. This rise in the real rate of interest is caused by an expected decline in the future relative price of non-tradable goods. As this real interest rate effect reduces the smoothness of the consumption path, it plays only a small role for relatively low values of $\theta .^{17}$ However, it becomes more relevant for higher values of $\theta$, so that, with the rise in consumption lagging behind the rise in productivity and income, the current account turns positive.

28. The magnitude of the current account reaction also hinges on the speed at which productivity converges towards its new steady-state level. In the extreme case $\rho^{a}=0$ (meaning that productivity jumps instantaneously to its new level), consumers immediately adjust their consumption to the new level of income (Figure 1, dashed line), so that their saving rate and, hence, the current account position remain unchanged.

29. Finally, the saving and current account effects of productivity shocks vary depending on whether the shock occurs in the tradable or non-tradable goods sector. ${ }^{18}$ To illustrate this, a permanent productivity increase in the tradable sector is first considered (solid line in Figure 4). The short-run current account reaction is driven by two factors: First, as in the baseline case, consumers seek to benefit from the future rise in income by consuming more already today. The rise in the desired level of consumption for all three goods raises the price of non-tradables relative to that of tradables and the price of home-made tradables relative to foreign-made tradables. Second, consumers frontload consumption since they expect the relative price of non-tradable goods to rise over time as productivity in the tradable sector converges towards its higher level (this expected rise in the relative price of non-tradables reduces the real interest rate in terms of the consumption good, ceteris paribus). Since both effects work in the same direction the magnitude of the current account reaction is larger than in the case of an economy-wide shock under which the initial rise in the relative price of non-tradables is reversed over time (and thus partially offsets the rise in the desired level of consumption that stems from inter-temporal consumption smoothing). For the same reason, the direction of the initial current account reaction is independent of the inter-temporal elasticity of substitution in the case of a productivity shock in the tradable goods sector.

16. Since the rise in consumption is stronger than in the baseline case, the demand for bonds rises by more, implying a stronger increase in the interest rate.

17. For reasons of simplicity, the real interest rate effect was ignored in the discussion of the low- $\theta$ baseline case since it is dominated by the inter-temporal consumption smoothing effect.

18. Results presented here do not depend on the assumption that the non-tradable sector represents a large share of the economy. 
30. If the rise in productivity is restricted to the non-tradable sector, the sign of the immediate current-account response depends on the magnitude of the inter-temporal elasticity of substitution (relative to the intra-temporal elasticity of substitution), similar to the baseline case (Figure 5). However, such a shock is more likely to yield a negative current account response than in the baseline case. Indeed, for a productivity shock in the non-tradable sector to show a positive current account reaction in the initial period, a larger value of $\theta$ is necessary than in the case of an economy-wide productivity shock. The relative price of non-tradable goods is expected to fall over time, which induces consumers to postpone consumption. Depending on the value of the inter-temporal elasticity of substitution $\theta$, this effect partially offsets or even dominates consumers' attempts to smooth consumption over time. The likelihood of a positive current account response, and also the magnitude of this response, is larger than in the baseline case because the expected decline in the relative price of non-tradable goods is stronger, implying a higher real interest rate for consumers.

\section{Conclusion}

31. Using a simple DSGE model, this paper shows that the current account effects of a productivity shock are theoretically ambiguous and depend on many factors, including in particular consumers' preferences for consumption smoothing, their beliefs on whether the rise in the level of productivity is permanent or temporary, and the sector in which the shocks occurs. The model could be extended in several ways, for example by incorporating capital accumulation or uncertainty - the latter allowing, for instance, to explore the precautionary saving behaviour of households. However, such extensions would not alter the main message of this paper, which is that the sign of the current account response to productivity shocks depends on both shock features and on parameters that are to be estimated. Given these theoretical complexities and ambiguities, the impact of productivity shocks on saving and current accounts ultimately remains an empirical issue. 


\section{REFERENCES}

de Mello, L. and P. C. Padoan (2010), "Promoting Potential Growth: The Role of Structural Reform", OECD Economics Department Working Papers No. 793.

Dornbusch, R. (1983), "Real Interest Rates, Home Goods, and Optimal External Borrowing," Journal of Political Economy, Vol. 91, pp. 141-153.

Ferrero, A., M. Gertler and L. Svensson (2010), "Current Account Dynamics and Monetary Policy", in: Galí, J. and M. Gertler (eds.), International Dimensions of Monetary Policy, University of Chicago Press.

Gruber, J. (2006), “A Tax-Based Estimate of the Elasticity of Intertemporal Substitution”, NBER Working Papers No 11945.

Guvenen, F. (2006), "Reconciling Conflicting Evidence on the Elasticity of Intertemporal Substitution: A Macroeconomic Perspective", Journal of Monetary Economics, Vol. 53, pp. 1451-1472.

Hall, R. E. (1988), "Intertemporal Substitution in Consumption”, Journal of Political Economy, Vol. 96, pp. 339-357.

IMF (2010), "G-20 Mutual Assessment Process - Alternative Policy Scenarios", report prepared for the G20 Toronto Summit, June 26-27, 2010.

Kerdrain, C., Koske, I. and I. Wanner (2010), “The Impact of Structural Policies on Saving, Investment and Current Accounts", OECD Economics Department Working Papers No. 815.

Laffargue, J.-P. (1990), "Résolution d'un Modèle Macroéconomique avec Anticipations Rationnelles", Annales d'Économie et de Statistique, Vol. 17, pp. 97-119.

Mendoza E. G. and L. L. Tesar (1998), "The International Ramifications of Tax Reforms: Supply-Side Economics in a Global Economy", American Economic Review, Vol. 88, pp. 226-245.

Obstfeld, M. and Rogoff, K. (1996), Foundations of International Macroeconomics, The MIT Press.

Schmitt-Grohe, S. and M. Uribe (2002), "Solving Dynamic General Equilibrium Models Using a SecondOrder Approximation to the Policy Function”, NBER Technical Working Papers No. 0282.

Yogo, M. (2004), "Estimating the Elasticity of Intertemporal Substitution when Instruments are Weak", Review of Economics and Statistics, Vol. 86, pp. 797-810. 
Figure 1. Permanent economy-wide productivity shock - alternative values for the speed of adjustment of productivity to its new steady state
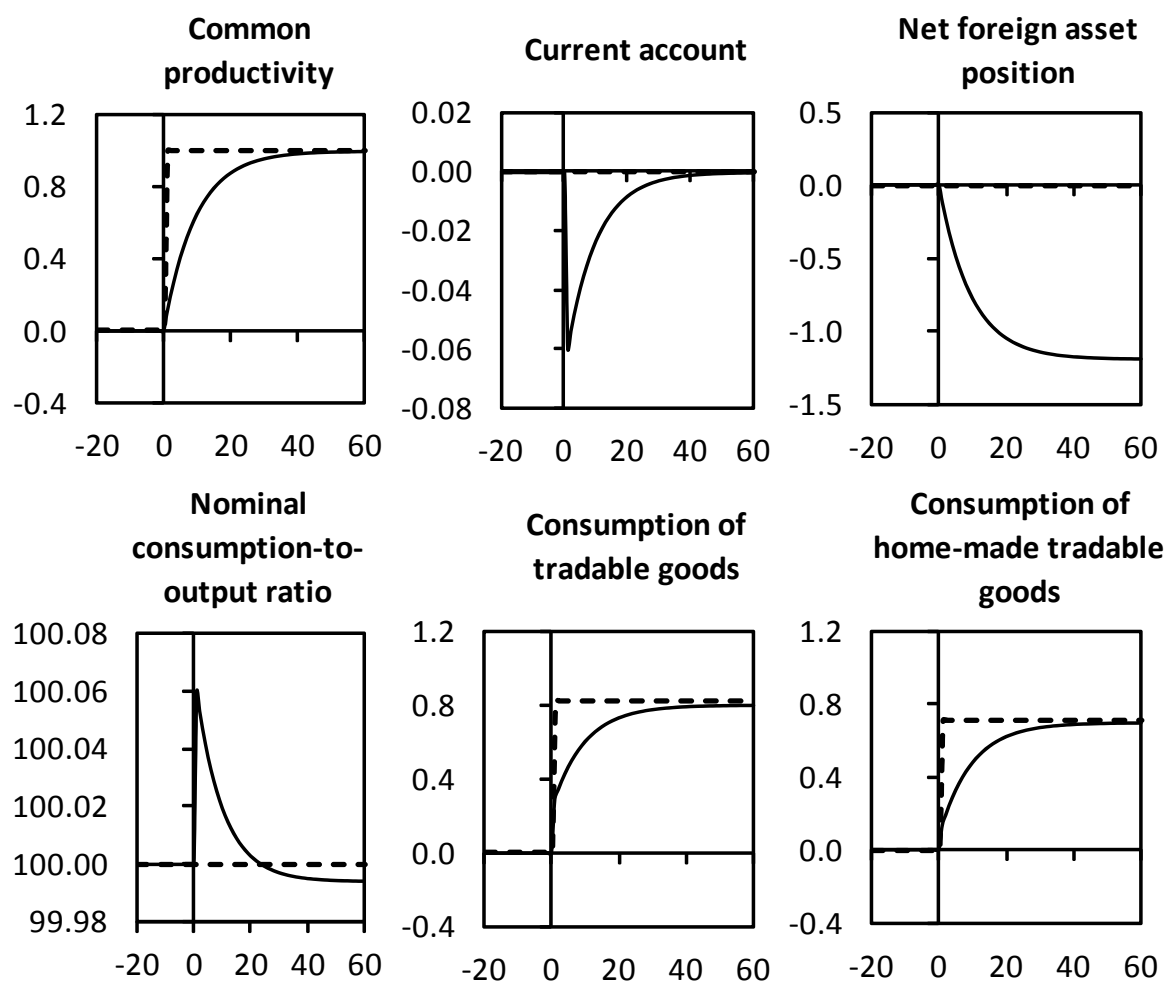

Consumption of
home-made tradable
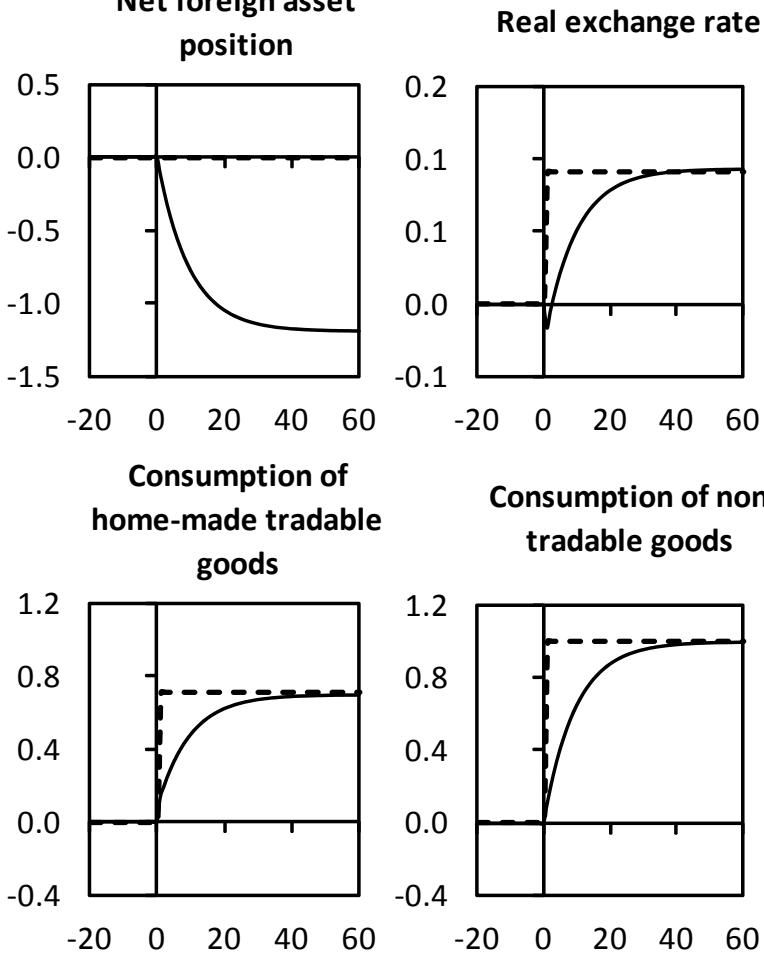

Consumption of nontradable goods

Interest rate

Home production of tradable goods
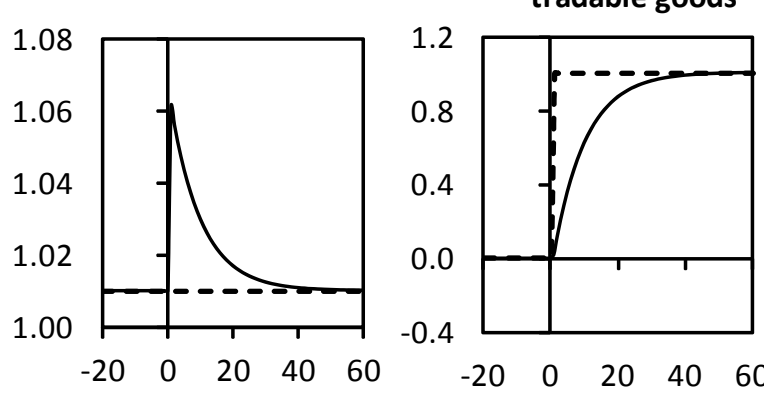

Prod. of tradable goods abroad
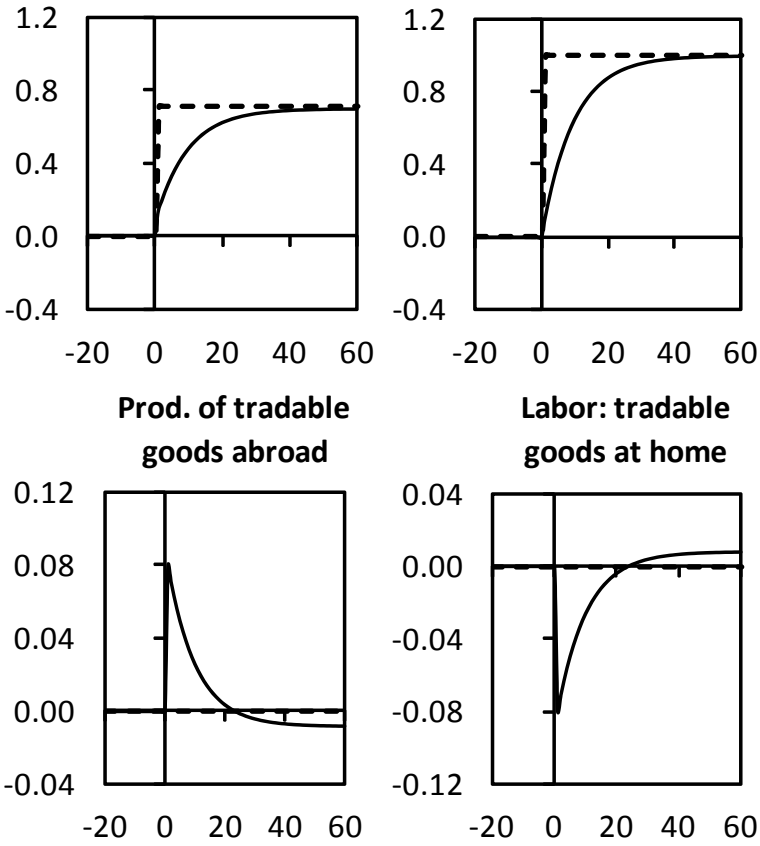

Price of nontradables at home Price of home-made tradables
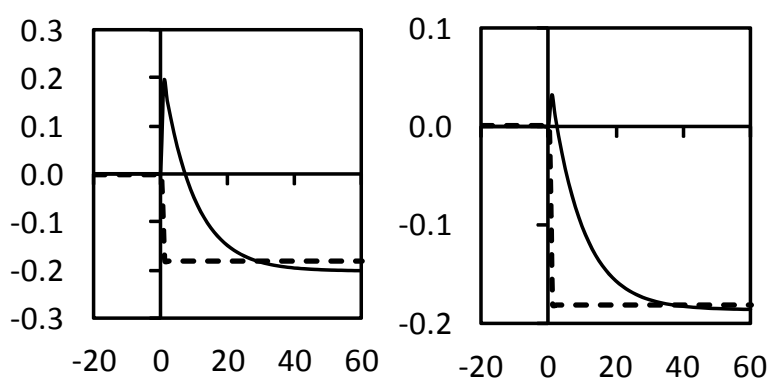

Terms of trade

Net exports
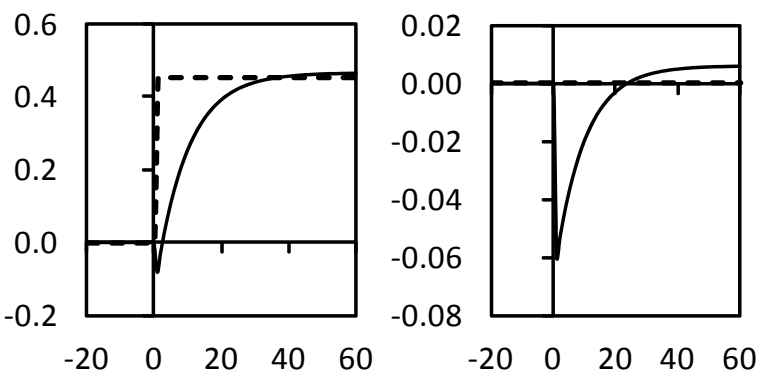

- - Instantaneous shift

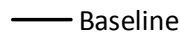

Notes: Simulated effect of a $0.1 \%$ rise in productivity, multiplied by a factor of 10 . Deviation from initial steady state in \%, except for total consumption, the current account, net foreign assets and net exports (all measured as share of output). 
Figure 2. Temporary economy-wide productivity shock - alternative values for the inter-temporal elasticity of substitution

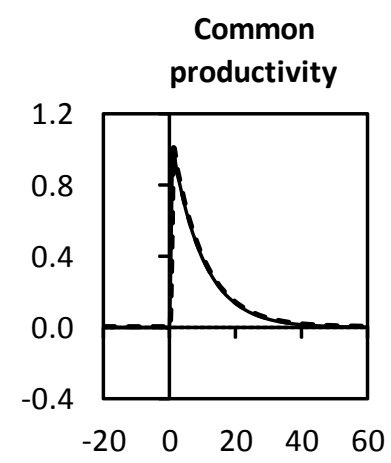

Nominal consumption-tooutput ratio
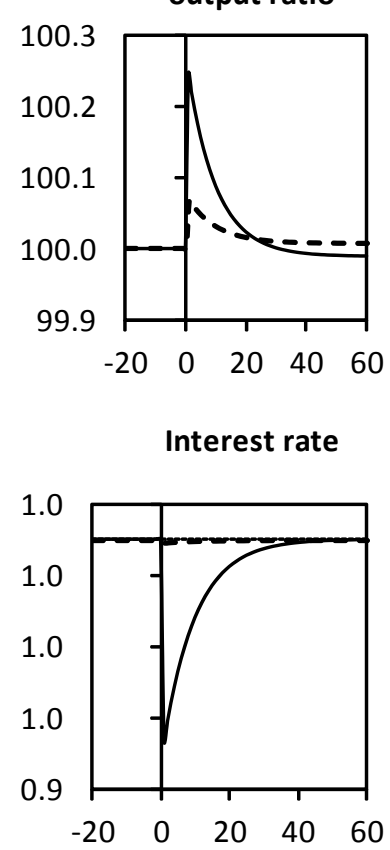

Price of tradables at home

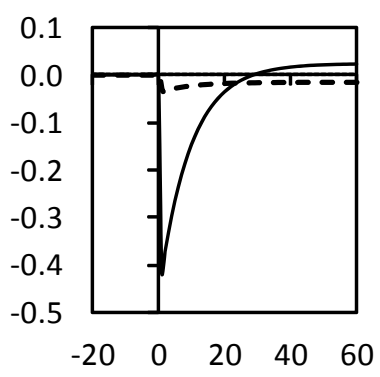

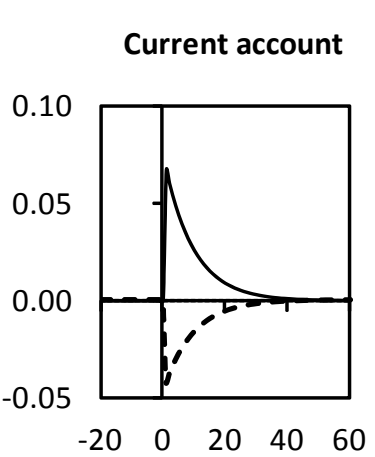

Consumption of tradable goods

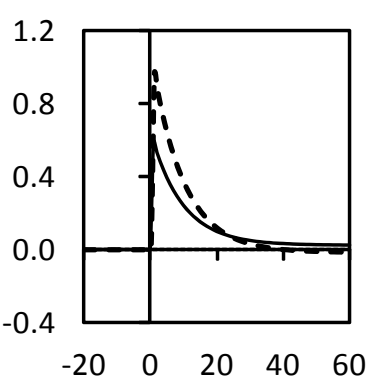

Home production of tradable goods

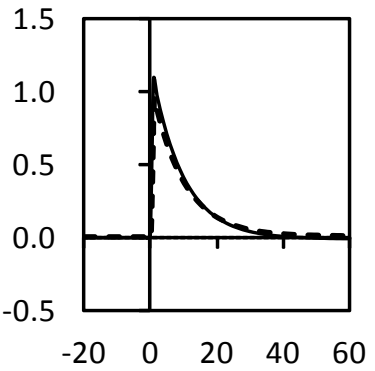

Price of home-made tradables

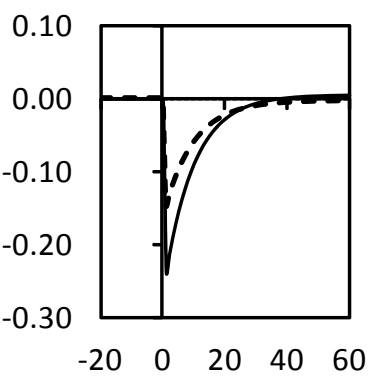

Net foreign asset position

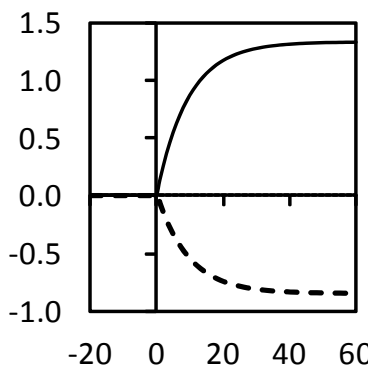

Consumption of home-made tradable goods

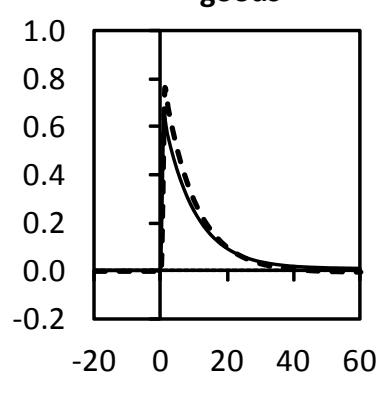

Prod. of tradable goods abroad

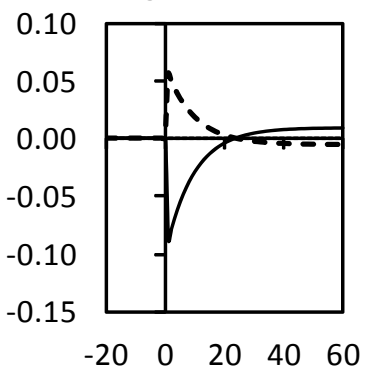

Terms of trade

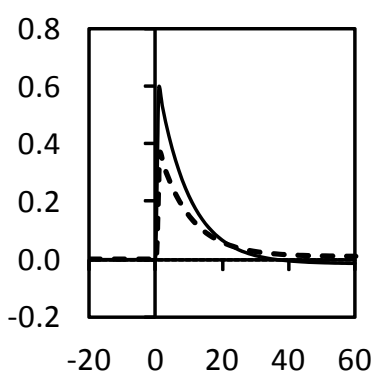

Real exchange rate

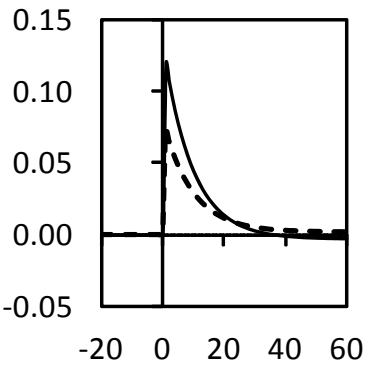

Consumption of nontradable goods
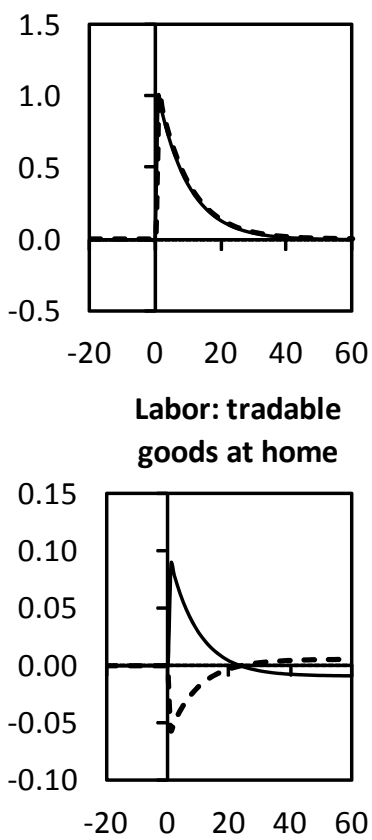

Net exports

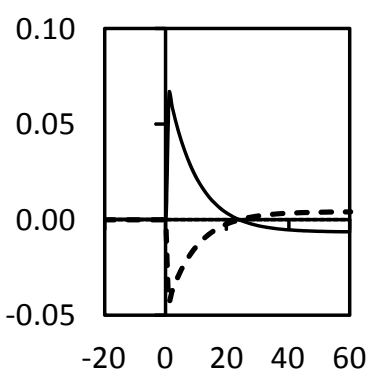

- - High intertemporal elasticity of substitution $(\theta=10)$

_ Parameter values as in the baseline (Table 2)

Notes: Simulated effect of a $0.1 \%$ rise in productivity, multiplied by a factor of 10 . Deviation from initial steady state in \%, except for total consumption, the current account, net foreign assets and net exports (all measured as share of output). 
Figure 3. Permanent economy-wide productivity shock - alternative values for the inter-temporal elasticity of substitution

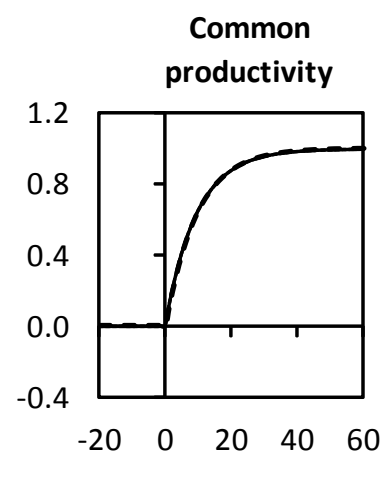

Nominal consumption-tooutput ratio

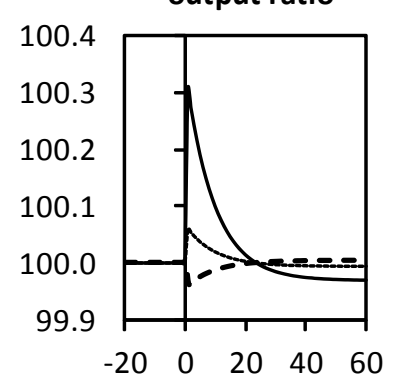

Interest rate

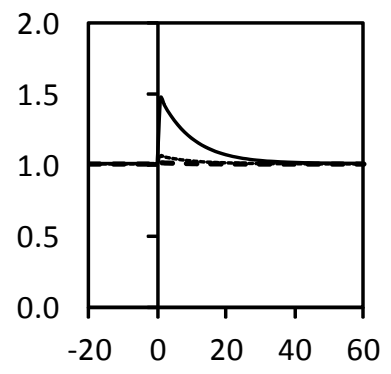

Price of nontradables at home

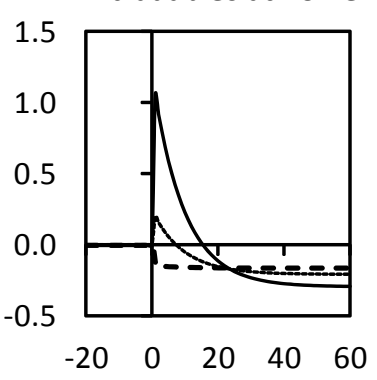

Net foreign asset position

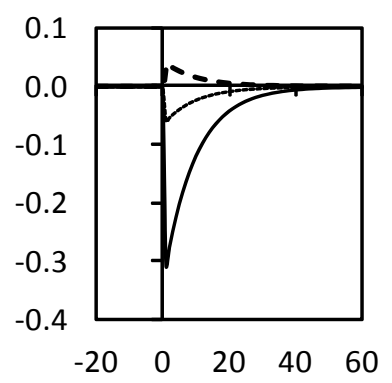

Consumption of tradable goods

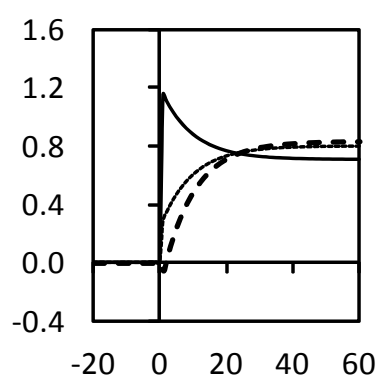

Home production of tradable goods

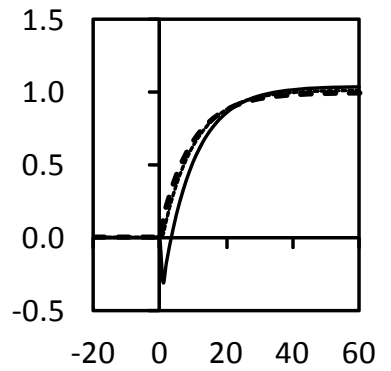

Price of home-made tradables

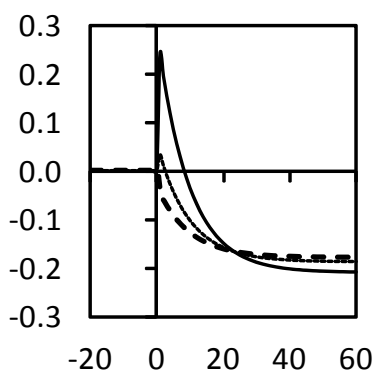
goods

Prod. of tradable goods abroad

Terms of trade
Real exchange rate

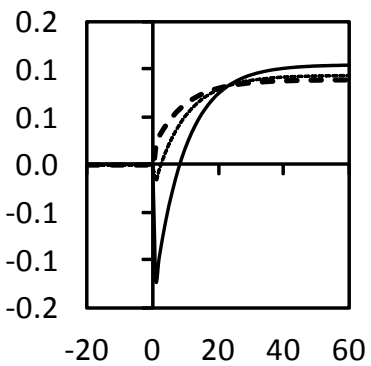

Consumption of nontradable goods

home-made tradable
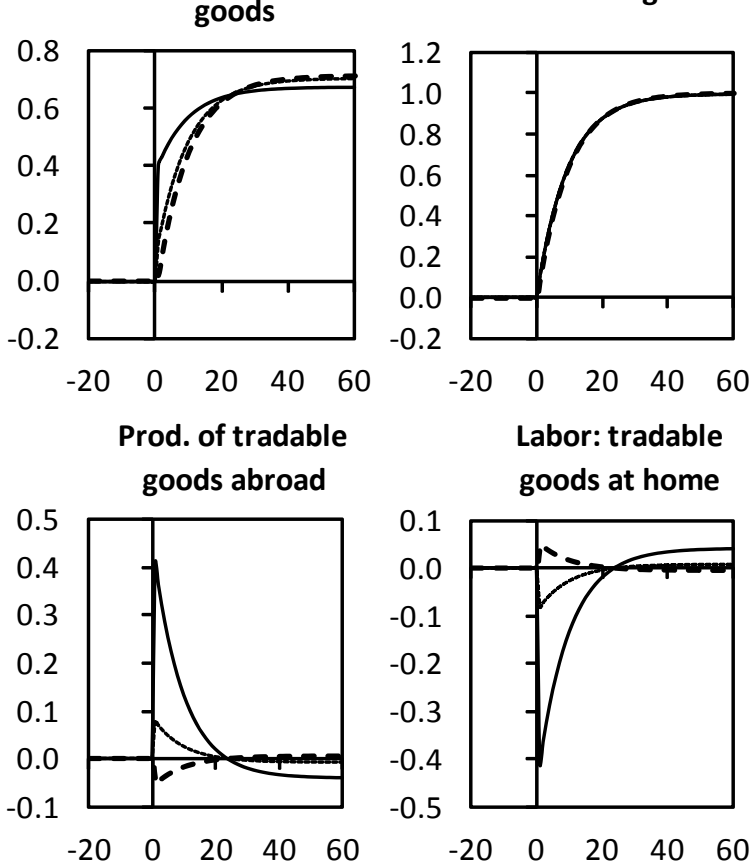

Labor: tradable goods at home
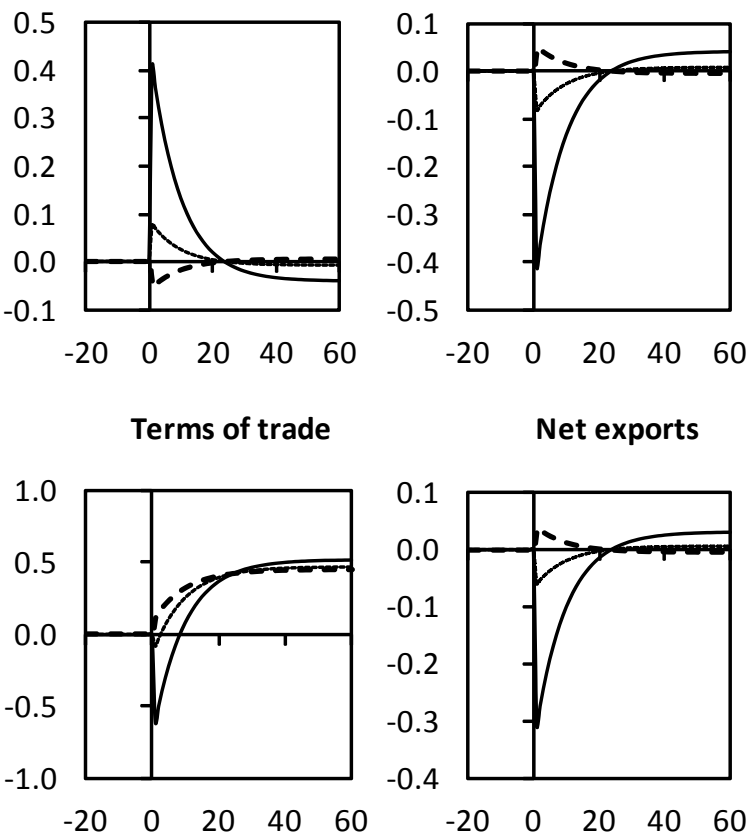

Net exports

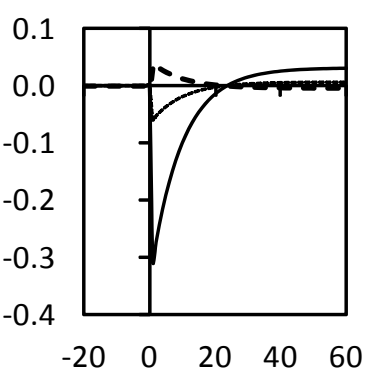

- - High intertemporal elasticity of substitution $(\theta=10)$

L Low intertemporal elasticity of substitution $(\theta=0.1)$

-.-.-- Intermediate intertemporal elasticity of substitution $(\theta=1)$

Notes: Simulated effect of a $0.1 \%$ rise in productivity, multiplied by a factor of 10 . Deviation from initial steady state in \%, except for total consumption, the current account, net foreign assets and net exports (all measured as share of output). 
Figure 4. Permanent productivity shock in the tradable goods sector

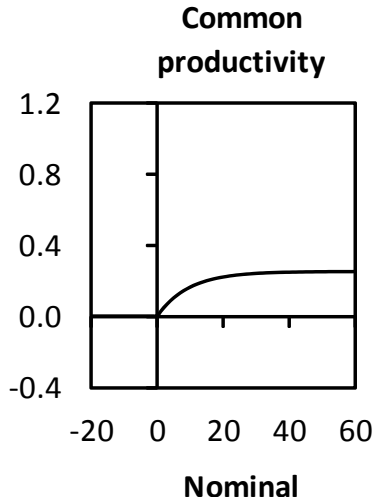
consumption-tooutput ratio

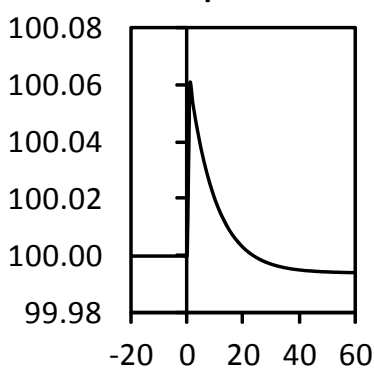

Interest rate

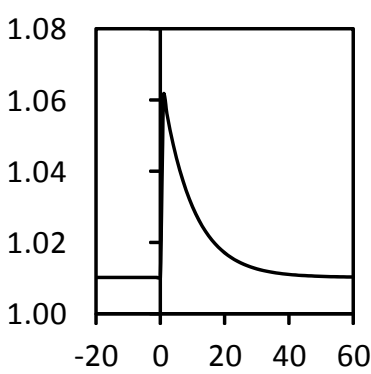

Price of nontradables at home

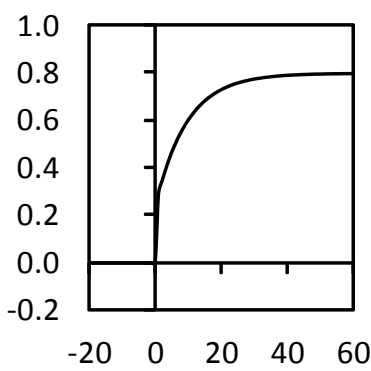

Current account

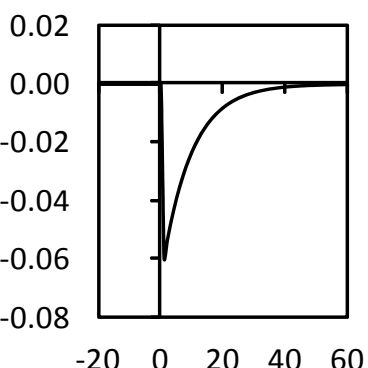

Consumption of tradable goods

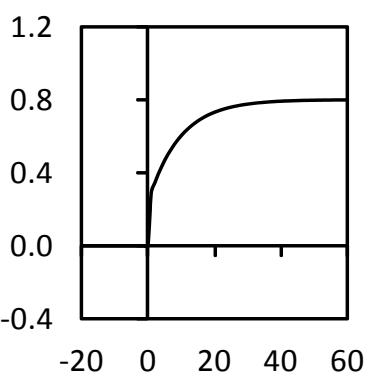

Home production of tradable goods

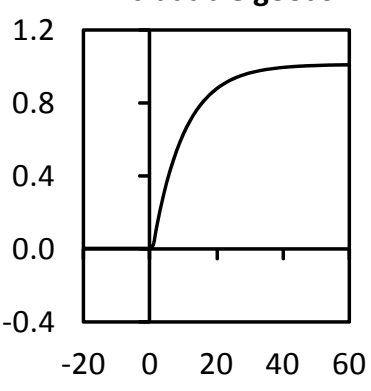

Price of home-made tradables

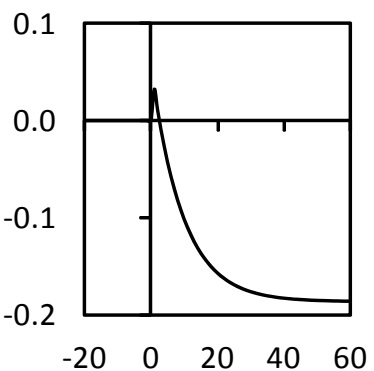

Net foreign asset position

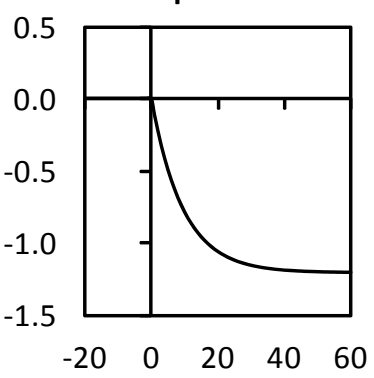

Consumption of home-made tradable goods

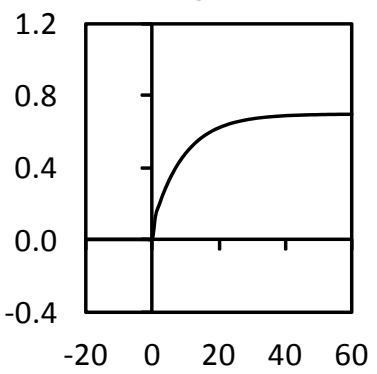

Prod. of tradable goods abroad

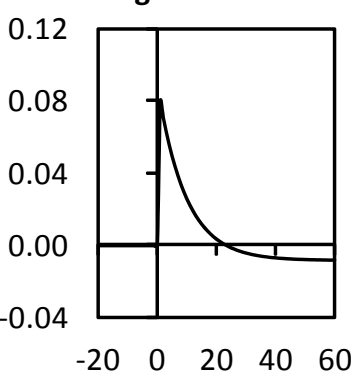

Terms of trade

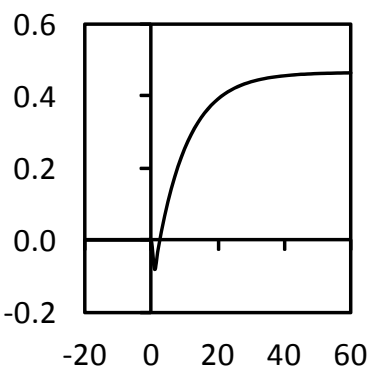

Real exchange rate

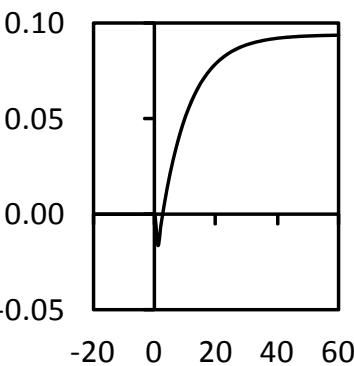

Consumption of nontradable goods

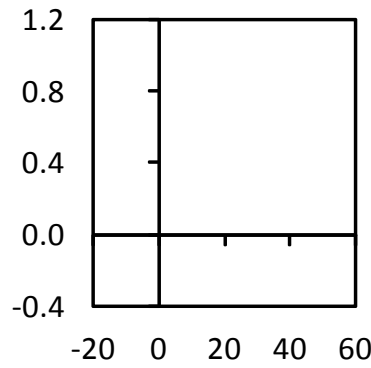

Labor: tradable

goods at home

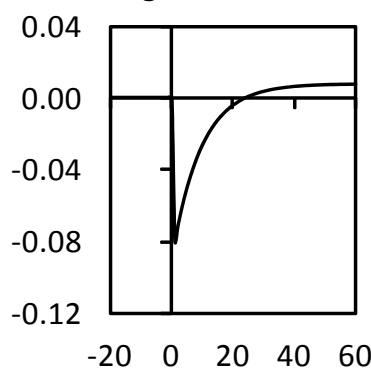

Net exports

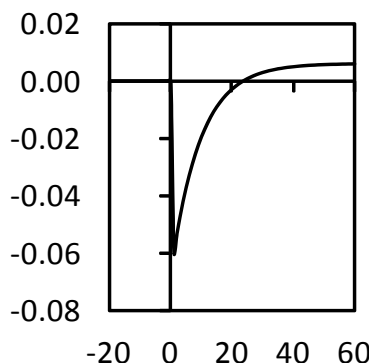

Notes: Simulated effect of a $0.1 \%$ rise in productivity, multiplied by a factor of 10 . Deviation from initial steady state in \%, except for total consumption, the current account, net foreign assets and net exports (all measured as share of output). Parameter values as in the baseline. 
Figure 5. Permanent productivity shock in the non-tradable goods sector - alternative values for the inter-temporal elasticity of substitution

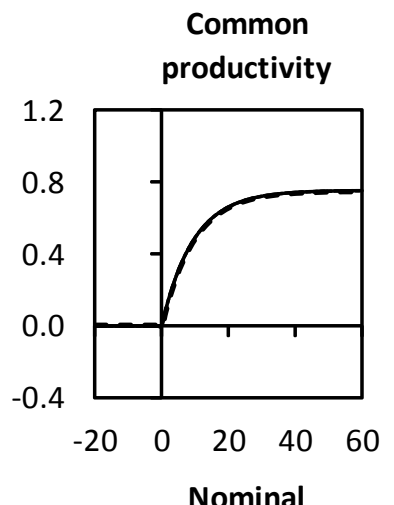

consumption-tooutput ratio

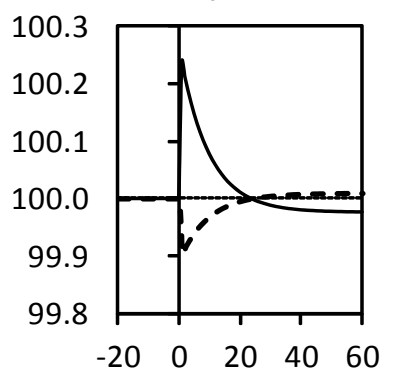

Interest rate

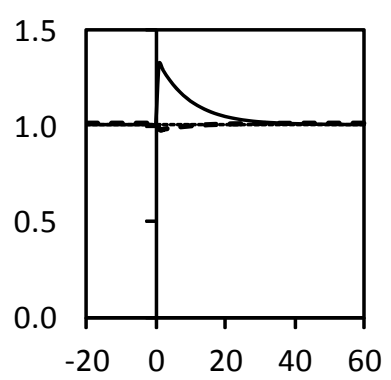

Price of non-

tradables at home

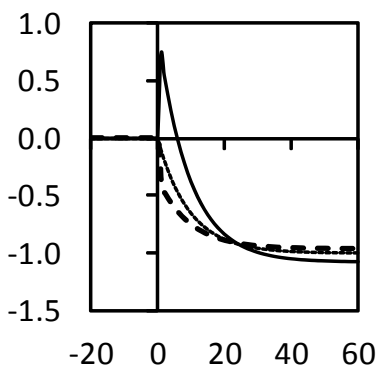

Current account

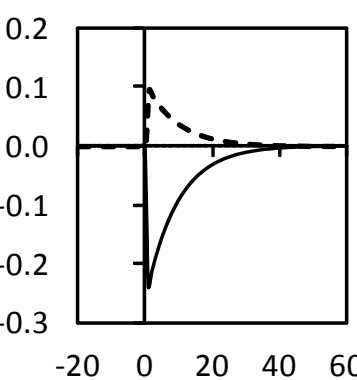

Consumption of tradable goods

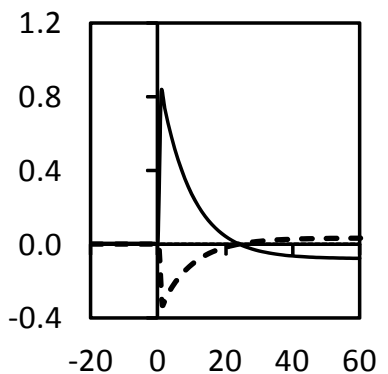

Home production of tradable goods

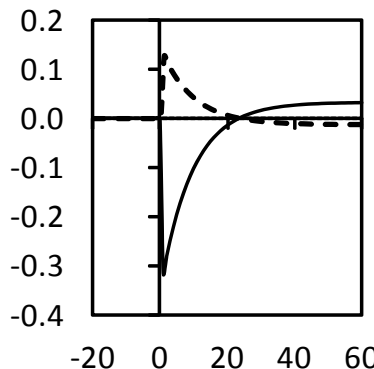

Price of home-made tradables

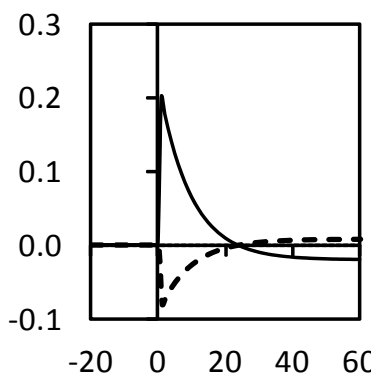

Net foreign asset position

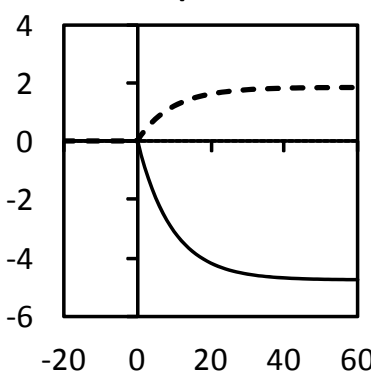

Consumption of home-made tradable goods

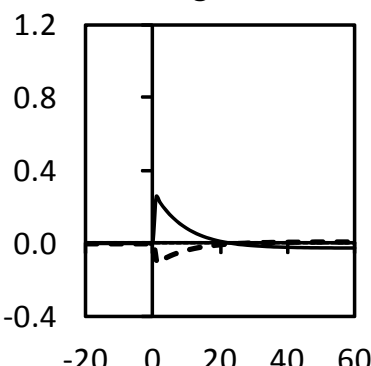

Prod. of tradable goods abroad

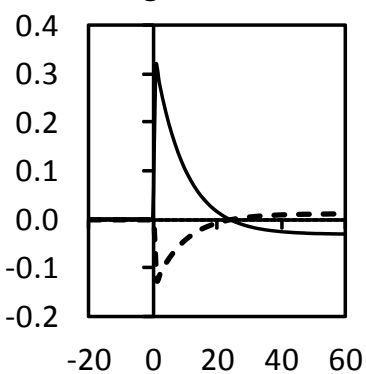

Terms of trade

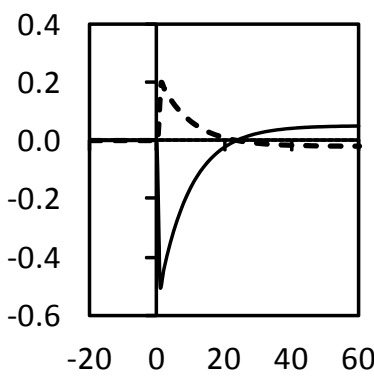

Real exchange rate

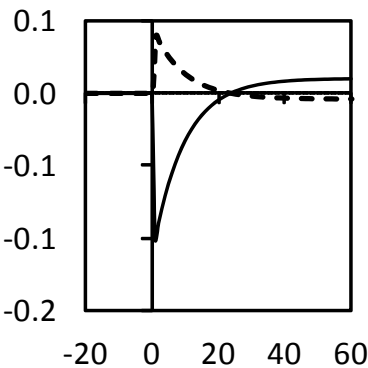

Consumption of nontradable goods
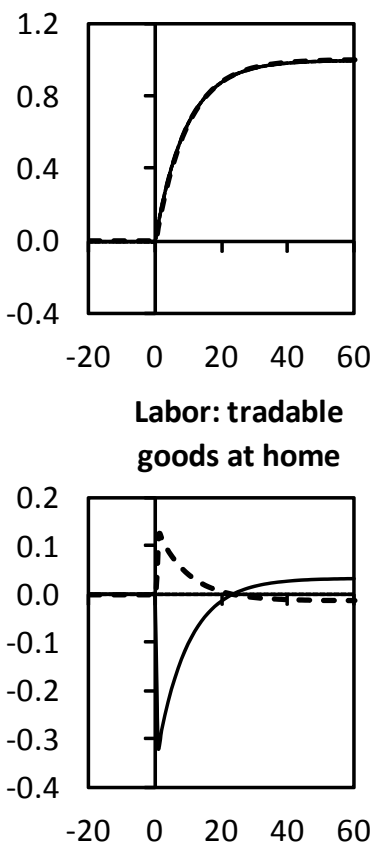

Net exports

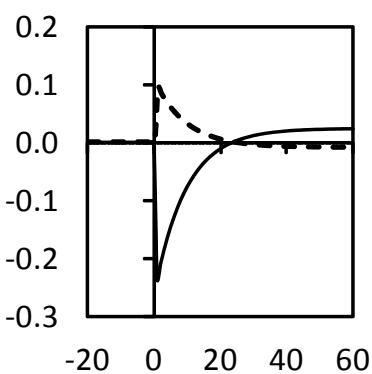

- - - High intertemporal elasticity of substitution $(\theta=10)$

- Low intertemporal elasticity of substitution $(\theta=0.1)$

Intermediate intertemporal elasticity of substitution $(\theta=1)$

Notes: Simulated effect of a $0.1 \%$ rise in productivity, multiplied by a factor of 10 . Deviation from initial steady state in $\%$, except for total consumption, the current account, net foreign assets and net exports (all measured as share of output). 


\section{WORKING PAPERS}

The full series of Economics Department Working Papers can be consulted at www.oecd.org/eco/workingpapers/

815. The impact of structural policies on saving, investment and current accounts (November 2010) by Clovis Kerdrain, Isabell Koske, Isabelle Wanner

814. Towards a less distortive and more efficient tax system in Portugal (November 2010) by Alvaro Pina

813. Are global imbalances sustainable? Shedding further light on the causes of current account reversals (November 2010) by Luiz de Mello, Pier Carlo Padoan, Linda Rousová

812. Turkey's improving integration with the global capital market: Impacts on risk premia and capital costs (November 2010) by Rauf Gönenç, Saygin Şahinöz, Özge Tuncel

811. Trade linkages in the OECD trade system (October 2010) by Jérôme Brézillon, Stéphanie Guichard and Dave Turner

810. Enhancing the effectiveness of social policies in Indonesia (October 2010) by Margherita Comola and Luiz de Mello

809. Tackling the infrastructure challenge in Indonesia (October 2010) by Mauro Pisu

808. Phasing out energy subsidies in Indonesia (October 2010) by Annabelle Mourougane

807. Implementing cost-effective policies in the United States to mitigate climate change (October 2010) by David Carey

806. Restoring fiscal sustainability in the United States

(October 2010) by Patrick Lenain, Bob Hagemann and David Carey

805. Norway: Sustainable development: climate change and fisheries policies (September 2010) by Paul O'Brien

804. Netherlands: How the transport system can contribute to better economic and environmental outcomes (September 2010) by Tomasz Koźluk

803. Public-private partnerships and investment in infrastructure (September 2010) by Sónia Araújo and Douglas Sutherland

802. Sustaining the momentum of fiscal reform (September 2010) by Colin Forthun and Robert Hagemann

801. The consequences of banking crises for public debt (September 2010) by Davide Furceri and Aleksandra Zdzienicka 
800. A simulation model of federal, provincial and territorial government accounts for the analysis of fiscal-consolidation strategies in Canada

(September 2010) by Yvan Guillemette

799. Product market regulation: extending the analysis beyond OECD countries (October 2010) by Anita Wölfl, Isabelle Wanner, Oliver Röhn, Giuseppe Nicoletti

798. Korea's green growth strategy: mitigating climate change and developing new growth engines (July 2010) by Randall S. Jones and Byungseo Yoo

797. Health-care reform in Korea

(July 2010) by Randall S. Jones

796. The Korean financial system: overcoming the global financial crisis and addressing remaining problems

(July 2010) by Masahiko Tsutsumi, Randall S. Jones and Thomas F. Cargill

795. Are global imbalances sustainable? Post-crisis scenarios

(July 2010) by Luiz de Mello and Pier Carlo Padoan

794. Is there a case for carbon-based border tax adjustment? An applied general equilibrium analysis (July 2010) by Jean-Marc Burniaux, Jean Chateau and Romain Duval

793. Promoting potential growth: The role of structural reform (July 2010) by Luiz de Mello and Pier Carlo Padoan

792. Catching-up and inflation in Europe: Balassa-Samuelson, Engel's law and other culprits (July 2010) by Balázs Égert

791. Do product market regulations in upstream sectors curb productivity growth? Panel data evidence for OECD countries (July 2010) by Renaud Bourlès, Gilbert Cette, Jimmy Lopez, Jacques Mairesse, Giuseppe Nicoletti

790. Preparing for Euro adoption in Poland

(July 2010) by Rafal Kierzenkowski

789. Gauging the impact of higher capital and oil costs on potential output (June 2010) by Boris Cournède

788. The German banking system: lessons from the financial crisis (June 2010) by Felix Hüfner

787. Measuring competition in Slovenian industries - estimation of mark-ups (June 2010) by Margit Molnar

786. Enhancing financial stability through better regulation in Hungary (June 2010) by Margit Molnar

785. Chile: Boosting productivity growth by strengthening competition, entrepreneurship and innovation (June 2010) by Cyrille Schwellnus 